Original

\title{
Phase II study: Combination of carboplatin and paclitaxel as second-line treatment in metastatic non-small-cell lung cancer
}

\author{
R. Espinosa, A. Sánchez, C. Maximiano, A. Hurtado, P. Espinosa, P. España
}

\section{Summary}

This study was designed to determine the efficacy and safety of the paclitaxel and carboplatin combination in second-line chemotherapy treatment of patients with non-small-cell lung cancer. Treatment consisted of $175 \mathrm{mg} / \mathrm{m}^{2}$ paclitaxel infused in 1 hour and carboplatin AUC 5 infused in 30 minutes, administered each 3 weeks for a maximum of 6 cycles. The following patient groups were included in the study: those who were stage IV at diagnosis; with progression during or after the administration of previous first-line chemotherapy; PS $\leq 2$ and with normal hepatic, renal and bone marrow function. Twenty-two patients were included between January 2000 and December 2002. Their clinical characteristics were: male $81 \%$ / female 19\%; adenocarcinoma histology in 12 patients (55\%) / squamous carcinoma in 6 patients (27\%) / large cell carcinoma in 2 patients (9\%), and other types in 2 patients (9\%). The Performance Status (ECOG Scale) was 0 in 5 patients $(22 \%), 1$ in 5 patients (22\%) and 2 in 12 patients (55\%). Previously administered treatments were: combinations with cisplatin in 11 patients (50\%) and combinations without cisplatin (ifosfamide, gemcitabine, vinorelbine) in 11 patients (50\%). The mean number of first-line chemotherapies received was 1 to 4 cycles in $50 \%$ patients. The mean number of second-line treatments was 1 to 3 cycles in $50 \%$ and 3 to 6 cycles in the others. The doses administered were $100 \%$ of that planned in 20 patients, with 2 patients requiring dose reductions due to neutropenia and grade 3 neurotoxicity. The treatment was well tolerated with presentation of the following grade 3-4 toxicities: neutropenia in 2 patients (9\%), peripheral neuropathy in 2 patients (9\%). The overall response rate was $23 \%$ (CI 95\%, 8-45): 5 patients (23\%) with partial response, 9 (36\%) with stable disease and $8(31 \%)$ with progression. The median time to progression with second-line treatment was 16 weeks, reaching a median overall survival of 79 weeks. From the initiation of secondline treatment median survival was 24.1 weeks (CI 95\%, 13.7-34.5).

In this study it was observed that the combination of paclitaxel with carboplatin as second-line chemotherapy in patients with non-small-cell lung cancer presented moderate/restrained activity without severe toxicity.

Key words: Metastatic non small cell lung cancer. Carboplatin. Paclitaxel. Second-line treatment.

Oncología, 2006; 29 (5):185-193

Medical Oncology Service

Clínica Puerta de Hierro. Madrid (España)
Recibido: 13.01 .06

Revisado: 18.01 .06

Aceptado: 17.02.06 


\section{Resumen}

Este estudio fue diseñado para determinar la eficacia y seguridad de la combinación de paclitaxel y carboplatino como quimioterapia de segunda línea de pacientes con cáncer de células no pequeñas de pulmón. El tratamiento consistió en la infusión de $175 \mathrm{mg} / \mathrm{m}^{2}$ de paclitaxel durante 1 hora y carboplatino AUC 5 durante 30 minutos, administrados cada 3 semanas con un máximo de 6 ciclos. Se incluyeron en el estudio tres grupos de pacientes: los diagnosticados de encontrarse en estadio IV; los que presentaron progresión durante o después de la administración previa de quimioterapia de primera línea; y los que tenían PS $\leq$ con funciones hepática, renal y ósea normales. Se incluyeron veintidós pacientes entre enero de 2000 y diciembre de 2002. Sus características clínicas fueron: varones $81 \% / m u-$ jeres 19\%; histología de adenocarcinoma 12 pacientes (55\%)/carcinoma escamoso 6 pacientes $(27 \%) /$ carcinoma de células grandes 2 pacientes (9\%)/otros tipos histológicos 2 pacientes (9\%). Los tratamientos administrados previamente fueron: combinaciones con cisplatino en 11 pacientes (50\%) y combinaciones sin cisplatino (ifosfamida, gemcitabina, vinorelbina) en 11 pacientes (50\%). En la quimioterapia de primera línea, el 50\% de los pacientes recibió en promedio 1 a 4 ciclos. Como quimioterapia de segunda línea se administraron 1 a 3 ciclos en el 50\% de los casos y 3 a 6 ciclos en el otro $50 \%$. Las dosis administradas fueron el 100\% de las planeadas en 20 pacientes, en tanto que en 2 fue necesario reducir las dosis por la aparición de neutropenia y neurotoxicidad de grado 3 . El tratamiento fue bien tolerado en general, observándose en cuatro pacientes toxicidad de grados 3 y 4: neutropenia en 2 de ellos (9\%) y neuropatía periférica en otros 2 (9\%). En conjunto, respondió el 23\% de los enfermos (CI 95\%, 8-45): 5 pacientes (23\%) con respuesta parcial, 9 casos (36\%) con enfermedad estable y 8 enfermos $(31 \%)$ con progresión. El tiempo medio de la progresión con el tratamiento de segunda línea fue de 16 semanas, alcanzando una supervivencia global media de 79 semanas. Desde el comienzo del tratamiento de segunda línea la supervivencia media fue de 24,1 semanas (CI 95\%, 13,7-34,5).

En este estudio se observó que los pacientes con cáncer de células no pequeñas de pulmón que recibieron la combinación de paclitaxel y carboplatino como tratamiento de segunda línea presentaron una restricción moderada de actividad sin gran toxicidad.

\section{Palabras claves:}

Cáncer de células no pequeñas de pulmón. Carboplatino. Paclitaxel. Tratamiento de segunda línea.

\section{Introduction}

Standard chemotherapy treatment in advanced non-small-cell lung cancer is based on combinations with cisplatin, prolonging survival and improving the performance status (PS). However, considerable toxicity is associated to this drug, therefore less toxic options have been sought. Comparative studies of regimens with and without cisplatin have shown clear differences with respect to toxicity without finding any significant differences in relation to response rates and overall survival. Disease pro- gression after treatment with first-line chemotherapy is the rule. Second-line chemotherapy treatments are less standardized and, in general, drugs that are not used in first-line treatments and which have the lowest possible toxicity are administered.

Our study was designed to evaluate the efficacy of treatment with carboplatin and paclitaxel in second-line chemotherapy. This combination is a standard in first-line treatment with a good toxicity profile and which can be administered in outpatient departments, two criteria which we believe could be useful when considering its use as a second-line. 
Moreover, we evaluated whether the response to second-line platinum was different according to whether or not it was administered in the first-line, as well as the overall benefits which platinum based drugs could contribute when used as second-line treatments.

\section{Materials and methods}

\section{Criteria for inclusion/exclusion}

The criteria for inclusion were as follows: histologically demonstrated non-small-cell lung cancer (NSCLC), surgically untreatable advanced or metastatic disease, progression of the disease during or after at least one previous line of chemotherapy (which did not include paclitaxel), Karnofsky greater than or equal to $70 \%$ or a PS less than or equal to 2 , a minimum of one previously un-irradiated measurable lesion of at least $20 \mathrm{~mm}$ in one dimension, more than 18-years-of-age, hematological functions: Hemoglobin > $10 \mathrm{~g} / \mathrm{dl}$, neutrophils > $1500 \times 10^{6} / \mathrm{L}$, platelets $>100,000 \times 10^{6} / \mathrm{L}$, suitable renal and hepatic function (serum creatinine $<2$ $\mathrm{mg} / \mathrm{dl}$, bilirubin $<2 \mathrm{mg} / 100 \mathrm{ml}$ ), informed consent.

The criteria for exclusion were: presence of tumours other than NSCLC, infections or serious diseases, pregnancy, non-compliance with the inclusion criteria.

\section{Therapeutic scheme}

One hour infusion of $175 \mathrm{mg} / \mathrm{m}^{2}$ paclitaxel in dextrose. A 30 minute infusion of AUC 5 dose Carboplatin was administered after the infusion of paclitaxel every 3 weeks.

Pre-medication with $8 \mathrm{mg}$ IV Dexametasone 2418-12 and 6 hours before the paclitaxel, $50 \mathrm{mg}$ oral Difenhydramine and $300 \mathrm{mg}$ IV Cimetidine $30 \mathrm{mi}-$ nutes before the paclitaxel. A maximum of 6 cycles were planned.

\section{Toxicity and dose reduction}

Toxic effects were graded according to the new NCI (National Cancer Institute) toxicity criteria $(\mathrm{CTC}): 1=$ mild, $2=$ moderate, $3=$ severe, $4=$ risk of death.

\section{Hematological toxicity}

- Doses of paclitaxel and carboplatin were reduced in grade IV neutropenia (neutrophils $<500 \times 10^{6} / \mathrm{L}$ longer than or equal to 7 days), febrile neutropenia (neutrophils $<500 \times 10^{6} / \mathrm{L}, \mathrm{T}^{\mathrm{a}}>38.5^{\circ} \mathrm{C}$ ) or grade IV anaemia $(\mathrm{Hb}<6.5 \mathrm{~g} / \mathrm{dl})$. Treatment was delayed until hematological recovery in all cases of grade IV toxicity (neutrophils greater than or equal to 1500 , platelets greater than or equal to $\left.100,000 \times 10^{6} / \mathrm{L}\right)$. If hematological recovery was not reached by the $22^{\text {nd }}$ day, the following cycle was delayed for a maximum of 2 weeks. Patients were treated immediately once their absolute neutrophil and platelet recount recovered.

- Patients were withdrawn from the study if they did not reach hematological recovery before the $36^{\text {th }}$ day of the cycle.

\section{Gastrointestinal toxicity}

- In the event of grade 3-4 mucositis or diarrhoea, the doses of the two drugs were reduced by one level.

\section{Neurological toxicity}

- In the event of grade 3-4 neuropathy, the patient was withdrawn from the protocol. In the event of grade 2 neuropathy, the drug dose was reduced by one level.

\section{Renal toxicity}

- If creatinine clearance was less than 50 $\mathrm{mg} / \mathrm{ml} / \mathrm{min}$ the patient was withdrawn from the protocol.

\section{Hepatic toxicity}

- In the event of grade 3 hyperbilirubinemia (3-10 $\mathrm{mg} / 100 \mathrm{ml})$, the dose of both drugs was reduced by one level. In the event of grade 4 hyperbilirubinemia (greater or equal to $10 \mathrm{mg} / 100 \mathrm{ml}$ ), the patient was withdrawn from the protocol.

\section{Hypersensitivity reaction}

The infusion of paclitaxel was interrupted in cases of severe hypersensitivity which manifested as: 
hypotension requiring pressor treatment, angioedema, respiratory insufficiency requiring bronchodilation therapy, generalized urticaria.

\section{Evaluation of treatment}

Before undergoing treatment, a complete clinical history was required for each patient together with a physical examination including PS evaluation, thorax CT, upper hemiabdominal ultrasound or CT, thoracic X-ray, histology of the primary tumour, complete hemogram with platelet count, blood coagulation and biochemical tests including renal and hepatic function parameters, alkaline phosphatase and dehydrogenase lactate.

Treatment response controls were performed by CT each 2 cycles.

\section{Statistical evaluation methods}

The overall survival and free of progression curves were produced using the Kaplan-Meier method. Overall survival was defined as the interval between the initiation of treatment and death due to the tumour. Survival after second-line chemotherapy was defined as the interval between the initiation of treatment and death due to the tumour; and time free of progression was defined as the interval between the conclusion of treatment and tumour progression. The curves obtained by this method were compared using the log-rank test. All tests were two-tailed.

\section{Results}

\section{Patient characteristics}

Between January 2000 and December 2002, 22 patients were included in the study with an 18/4 male/female ratio. The mean age was 57 years (CI $95 \%, 40-67)$. All patients presented stage IV with progression after a line of chemotherapy which did not include paclitaxel. Histological types were adenocarcinoma in 12 patients (55\%), squamous carcinoma in 6 patients $(27 \%)$, large cell carcinoma in 2 patients (9\%), and other types in 2 patients (9\%). Performance Status (ECOG Scale) was 0 in 5 patients (22\%), 1 in 5 patients (22\%), and 2 in 12 patients $(55 \%)$. Previously administered treatments were: combinations with cisplatin in 11 patients $(50 \%)$, and combinations without cisplatin (ifosfamide, gemcitabine, vinorelbine) in 11 patients $(50 \%)$. The mean number of first-line chemotherapies received was 1 to 4 cycles in 50\% patients.

\section{Response and survival}

The overall response from the 22 patients treated was 23\% (95\% CI, 8-45), consisting of 5 partial responses (PR), 9 stable disease (SD), and 8 disease progression (PD).

A comparative study was performed between patients who received first-line chemotherapy with and without cisplatin, revealing a response rate of $27.3 \%$ in patients who received cisplatin, and $18.2 \%$ among those who did not, but without demonstrating any statistically significant difference.

The median time to progression with second-line treatment was 16 weeks, reaching a median overall survival of 79 weeks. From the initiation of secondline treatment median survival was 24.1 weeks (95\% CI, 13.7-34.5).

The median survival in patients who previously received cisplatin was 13.5 weeks (95\% CI, 0$27.6 \%)$ while in patients who did not receive this drug it was 16.3 weeks (95\% CI, 12.9-19.7), without any significant difference being found.

\section{Toxicity and dose reduction}

The mean number of second-line treatments was 1 to 3 cycles in $50 \%$, and 3 to 6 cycles in the others. The doses administered were $100 \%$ of that planned in 20 patients, with 2 patients requiring dose reductions due to neutropenia and grade 3 neurotoxicity. The treatment was well tolerated.

A total of 77 cycles of carboplatin plus paclitaxel were administered, with $50 \%$ of the patients included in the study receiving between 1 and 3 cycles, and the remaining $50 \%$ between 3 and 6 cycles. In 4 cycles $(5 \%)$ the dose was reduced to $75 \%$ in agreement with the modification criteria. Suspension of treatment was necessary in 1 case. The most frequent cause of dose reduction was hematological toxicity, specifically neutropenia; however, only 2 patients presented grade 3-4 toxicity (Table I). Episodes of cytopenia were brief (maximum 1 week). None of the patients presented febrile neutropenia. 
TABLE I

\section{Toxicity}

\begin{tabular}{|c|c|c|c|}
\hline Toxicity & $\begin{array}{c}\text { Grade } 2 \\
N^{o} \text { cycles }\end{array}$ & $\begin{array}{c}\text { Grade } 3 \\
N^{o} \text { cycles }\end{array}$ & $\begin{array}{c}\text { Grade } 4 \\
N^{o} \text { cycles }\end{array}$ \\
\hline Leucopoenia & 2 & 3 & 0 \\
\hline Anaemia & 8 & 4 & 0 \\
\hline Thrombopenia & 0 & 1 & 0 \\
\hline Alopecia & 5 & 1 & 0 \\
\hline Asthenia & 7 & 0 & 0 \\
\hline Neurotoxicity & 8 & 2 & 0 \\
\hline Arthralgia/myalgia & 1 & 0 & 0 \\
\hline Anorexia & 1 & 0 & 0 \\
\hline
\end{tabular}

One patient presented pneumonia without neutropenia.

The most frequent non-hematological toxicity was neurotoxicity, which was grade $2-3$ in 10 patients. Grade 2-3 alopecia presented in 6 patients, grade 2 asthenia in 7 patients, grade 2 anorexia in 1 patient, and grade 2 arthralgia/myalgia in 1 patient. None of the patients presented grade 2-4 nausea and/or vomiting.

\section{Discussion}

The results of various phase II and III trials show that a combination of paclitaxel and carboplatin administered every 3 weeks is efficacious and, in general, well tolerated as a first-line treatment in advanced non-small-cell lung cancer (1 year survival of $27 \%$ to $54 \%$ ). Moreover, recent phase III trials have demonstrated lower incidences of serious toxicity compared to regimens based on cisplatin ${ }^{1-5}$.

Over the last few years, a number of studies have demonstrated that chemotherapy can provide benefit in the second-line setting.

Paclitaxel has been studied as first-line monotherapy in one phase III trial ${ }^{6}$, and as a second-line in numerous phase II trials, either alone $e^{7-10}$ or in combination with other drugs ${ }^{11}$, in patients who had failed first-line chemotherapy. Different regimens have been used and response rates vary between $3 \%$ and $37 \%$, with a median survival of up to 9.7 months. Some of the results seem to be similar to docetaxel, but no direct comparison between them has been made, except for one phase II trial ${ }^{12}$ that was under- powered. Therefore, we considered the efficacy of paclitaxel is not well defined in second-line treatments.

Gemcitabine analogue nucleoside is efficacious as second-line treatment with an objective response rate of $7-25 \%$, and median survival of 22 to 33 weeks. In 1999, Gridelli ${ }^{13}$ published a phase II study which included 30 patients treated with second-line gemcitabine obtaining a response rate of $20 \%$ (CI $95 \%, 8-39 \%)$ and a progression free survival of 10 weeks. Sculier ${ }^{14}$ included 82 patients in another phase II second-line trial with a response rate of $6 \%$.

Kakolyris ${ }^{11}$ studied 49 patients receiving a gemcitabine and paclitaxel combination as second-line treatment, and obtained a response rate of $18 \%$ (CI $95 \%, 4-24 \%$ ) and a median survival of 16 weeks. With respect to toxicity, grade 3-4 neutropenia and thrombopenia were observed in $12 \%$ and $2 \%$ respectively, although only 1 patient presented febrile neutropenia. Grade 2 and 3 neurotoxicity was observed in $24 \%$ and $8 \%$ and grade $2-3$ asthenia in $51 \%$ (Table II).

The Hellenic co-operative Oncology Group published a study which included 39 patients with advanced non-small-cell lung cancer refractory or resistant to platinum or taxanes. They were treated with intravenous (IV) vinorelbine $25 \mathrm{mg} / \mathrm{m}^{2}$ on days 1 and 8 , followed by IV gemcitabine $800 \mathrm{mg} / \mathrm{m}^{2}$ every 3 weeks. Only one patient $(2.6 \%)$ achieved a partial response, 14 patients $(35.9 \%)$ had stable disease, and 24 patients had progression $(61.5 \%)$. The median time to progression was 4.7 months and the median survival was 7.3 months. The most notable toxicities were grade 3/4 neutropenia in two patients, febrile neutropenia in five patients and grade 4 fatigue in one patient ${ }^{15}$.

Docetaxel was approved by the Food and Drug Administration for the treatment of advanced, platinum-refractory non-small-cell lung cancer based on two large randomized trials ${ }^{16-17}$.

Shepherd ${ }^{16}$ published an international randomized controlled study which included 204 patients with non-small-cell lung cancer that had progressed after one line of chemotherapy. Patients were randomized to receive $100 \mathrm{mg} / \mathrm{m}^{2}$ or $75 \mathrm{mg} / \mathrm{m}^{2}$ docetaxel each 3 weeks, or palliative support treatment. The median survival of patients assigned to docetaxel was 28 weeks, this was longer than patients receiving sup- 
TABLE II

Reference studies published on 2nd line chemotherapy of non-small-cell lung cancer

\begin{tabular}{|c|c|c|c|c|c|c|}
\hline Study & Drugs & $\begin{array}{l}N^{o} \text { of } \\
\text { patients }\end{array}$ & Response rate & $\begin{array}{l}\text { Progression } \\
\text { Free survival }\end{array}$ & $\begin{array}{l}\text { Median } \\
\text { Survival }\end{array}$ & Toxicity \\
\hline $\begin{array}{l}\text { Phase II. } 1999 \\
\text { Gridelli C }\end{array}$ & Gemcitabine & 30 & $\begin{array}{c}20 \% \\
\text { IC } 95 \%=8-39 \%\end{array}$ & 10 weeks & 22 weeks & No severe toxicity. \\
\hline $\begin{array}{l}\text { Phase II. } 2000 \\
\text { Sculier JP }\end{array}$ & Gemcitabine & 82 & $6 \%$ & & & Thrombopenia g4 (3.65\%) \\
\hline $\begin{array}{l}\text { Phase II. } 2000 \\
\text { Kakolyris S. }\end{array}$ & $\begin{array}{l}\text { Gemcitabine + } \\
\text { Paclitaxel }\end{array}$ & 49 & $\begin{array}{c}18 \% \\
\text { IC } 95 \%=4-24 \%\end{array}$ & & 16 weeks & $\begin{array}{l}\text { Neutropenia g3-4 in } 12 \% \\
\text { Thrombopenia g3-4 in } 2 \% \\
\text { Neutropenia febrile in } 1 \text { patient } \\
\text { Neurotoxicity g2 in } 24 \% \text { and g3 in } 8 \% \\
\text { Asthenia g2-3 in 51\% }\end{array}$ \\
\hline $\begin{array}{l}1999 \\
\text { Nakanishi }\end{array}$ & $\begin{array}{l}\text { Cisplatin }+ \\
\text { Irinotecan }\end{array}$ & 21 & $29 \%$ & & & $\begin{array}{l}\text { Leucopoenia g3-4 in } 43 \% \\
\text { Anaemia in } 38 \% \\
\text { Thrombopenia en } 19 \% \\
\text { Diarrhoea g3 in } 38 \%\end{array}$ \\
\hline $\begin{array}{l}\text { Phase III, } 2000 \\
\text { Shepherd FA }\end{array}$ & $\begin{array}{l}\text { Docetaxel vs } \\
\text { support treatment }\end{array}$ & 204 & & & 28 weeks & $\begin{array}{l}\text { Febrile neutropenia ( } 22 \% \text { if dose } 100 \\
\mathrm{mg} / \mathrm{m}^{2} \text { and } 1.8 \% \text { if dose } 75 \mathrm{mg} / \mathrm{m}^{2} \text { ) }\end{array}$ \\
\hline $\begin{array}{l}\text { Phase III, } 2000 \\
\text { Fosella FV }\end{array}$ & $\begin{array}{l}\text { Docetaxel vs } \\
\text { Vinorelbine or } \\
\text { Ifosfamide }\end{array}$ & & & & $\begin{array}{l}\text { Range } 22 \text { to } \\
22.5 \text { weeks } \\
\text { similar between } \\
\text { the groups. }\end{array}$ & $\begin{array}{l}\text { Neutropenia g4 and febrile neutropenia } \\
\text { in Docetaxel were frequent. }\end{array}$ \\
\hline $\begin{array}{l}\text { Phase II, } 2001 \\
\text { Hellenic Group }\end{array}$ & $\begin{array}{l}\text { Vinorelbine } \\
\text { Gemcitabine }\end{array}$ & 39 & $2.6 \%$ & & 29.2 weeks & $\begin{array}{l}\text { Neutropenia g 3-4 }(5.1 \%) \text {, febrile } \\
\text { neutropenia }(12.8 \%) \text {, fatigue g4 }(2.6 \%)\end{array}$ \\
\hline $\begin{array}{l}2002 \\
\text { Laak E }\end{array}$ & $\begin{array}{l}\text { Docetaxel } \\
\text { Carboplatin }\end{array}$ & 26 & $19 \%$ & & 32.4 weeks & $\begin{array}{l}\text { Neutropenia g3-4 }(26.9 \%) \text {, febrile } \\
\text { neutropenia }(3.8 \%) \text {, anemia g3 } \\
(3.8 \%) \text {, alopecia g3 }(42.3 \%), \\
\text { neurotoxicity g2 }(7.7 \%) .\end{array}$ \\
\hline $\begin{array}{l}2002 \\
\text { Thongprasert S. }\end{array}$ & Docetaxel & 28 & $10.7 \%$ & & 23.8 weeks & $\begin{array}{l}\text { Neutropenia g } 3-4 \text { in } 38.8 \% \text { of cycles } \\
\text { Rash, asthenia, alopecia, neuropathy, } \\
\text { edema were frequent. }\end{array}$ \\
\hline $\begin{array}{l}\text { Phase II, } 2004 \\
\text { Espinosa R }\end{array}$ & $\begin{array}{l}\text { Carboplatin }+ \\
\text { Paclitaxel }\end{array}$ & 22 & $23 \%$ & 16 weeks & $\begin{array}{l}24.1 \text { weeks } \\
\text { (IC } 95 \%=13.7-34.5 \%)\end{array}$ & $\begin{array}{l}\text { Neutropenia g2-3 in } 2 \text { patients. } \\
\text { Neurotoxicity grade } 2-3 \text { in } 7 \text { patients. }\end{array}$ \\
\hline
\end{tabular}

port treatment but without statistical significance. One year after diagnosis, $37 \%$ of the patients treated with docetaxel were living, compared to $19 \%$ of the controls. In the patients who received $100 \mathrm{mg} / \mathrm{m}^{2}$ docetaxel, the rate of febrile neutropenia was $22 \%$, and $1.8 \%$ in those who received $75 \mathrm{mg} / \mathrm{m}^{2}$. Patients who received docetaxel required less opioid analgesic treatment and less palliative therapies than those who only received support treatment.

The other phase III trial was performed by Fose- lla and co-workers ${ }^{17}$, in which 373 patients were randomized to receive $100 \mathrm{mg} / \mathrm{m}^{2}$ docetaxel, 75 $\mathrm{mg} / \mathrm{m}^{2}$ docetaxel or the control arm with $30 \mathrm{mg} / \mathrm{m}^{2}$ vinorelbine or $2 \mathrm{~g} / \mathrm{m}^{2}$ ifosfamide. The median survival was similar between the patient groups (range 22 to 24.5 weeks); however, the 1 year survival rate was significantly greater in patients assigned to 75 $\mathrm{mg} / \mathrm{m}^{2}$ docetaxel than the control arm. Patients who received $75 \mathrm{mg} / \mathrm{m}^{2}$ docetaxel experienced a greater improvement in quality of life than those who recei- 
ved vinorelbine or ifosfamide. A high incidence of grade 4 neutropenia and febrile neutropenia was observed, but the incidence of infections was low and non-hematological toxicities were similar in all the treatments.

In 2002 Thongprasert and co-workers ${ }^{18}$ published the results of a phase II study which included 28 patients treated with docetaxel and found a response rate of $10.7 \%$ with a median survival of 23.8 weeks. Although the response rate to docetaxel is not impressive, the number of patients with stable disease was sufficient to increase survival rates and, with the improvement of symptoms, which led to this drug being accepted as the standard for care in this setting.

In a recent trial that compared docetaxel to the novel multitargeted antifolate, pemetrexed, in patients with chemotherapy-refractory disease, the response rates and survival rates did not differ, but the toxicity profile favoured pemetrexed ${ }^{19}$. Based on these findings, the Food and Drug Administration approved pemetrexed for the second-line treatment of advanced non-small-cell lung cancer.

In first-line treatment there is evidence that two drugs are better than one in terms of higher response rates, but significantly greater toxicity is seen in patients treated with combination chemotherapy. Survival is modestly improved with combination chemotherapy, but this is not significant when a more active drug was used as a single agent ${ }^{20}$. This may also be the case in second-line, where no drug combination has demonstrated superiority over a single agent. Although two drug combinations have not improved survival, and toxicities could be increased, doublets have been used in second-line treatment in order to improve response rates.

In 2001, Oka M and co. published a Phase I study of second-line treatment with docetaxel and carboplatin in advanced non-small-cell lung cancer ${ }^{21}$. One year later Laak E and co-workers published a pilot study which included 26 patients with stage IIIB/IV non-small-cell-lung cancer. They received docetaxel $75 \mathrm{mg} / \mathrm{m}^{2}$ followed by carboplatin AUC 5 on day 1 every 3 weeks. Five patients achieved a partial response (19\%), 11 had stable disease (42\%), and 10 progression (38\%). Median survival was 243 days and median progression-free survival was 118 days. They observed moderate haematological and mild non-haematological toxicities ${ }^{22}$.
Recently, Numico G and co-workers published a clinical trial including 48 patients, who received carboplatin AUC 6 on day 1, and paclitaxel 100 $\mathrm{mg} / \mathrm{m} 2$ on days 1,8 and 15 every 28 days. Previous platinum-based treatment had been received by 32 patients, while 16 were chemotherapy-naive. Response was achieved by 19 patients $(39.6 \%)$ without any difference between first- and second-line groups. One year survival was $39.5 \%$. The most common toxicities were grade 3-4 neutropenia in 16 patients $(33 \%)$, grade 3-4 thrombocytopenia in 7 patients (15\%), and grade 1-3 peripheral sensory neuropathy in 35 patients $(73 \%)^{23}$.

In Cancer (2003), Hensing and co-workers published a Phase III trial with paclitaxel and carboplatin as treatment in patients with non-small-cell lung cancer who were both older and younger than 70 -years-of-age. No statistically significant differences were identified in any of the most common toxicities. There were no differences in survival rates and quality of life between the two groups ${ }^{24}$.

In the last few years, investigators have developed novel therapeutic agents targeting specific molecules which play a role in tumour progression. Epidermal growth factor receptor (EGFR/HER1) is commonly overexpressed in a number of epithelial malignancies and is often associated with an aggressive phenotype [example, non-small-cell lung cancer (NSCLC)]. EGFR is present in over $50 \%$ of cases of NSCLC. Several EGFR-targeting agents have recently been developed, but the most important are the monoclonal antibody cetuximab, and the small molecules gefinitib and erlotinib ${ }^{25}$.

Gefinitib was licensed in May 2003 for use in advanced chemorefractory NSCLC in East Asia, the US and Australia (2 Phase II trials: IDEAL 1 and 2 ). The addition of gefitinib to chemotherapy regimens (paclitaxel and carboplatin) was generally well tolerated, and there was no apparent increase in higher-grade toxicity. Additional trials are evaluating gefitinib treatment in combination with chemotherapy ${ }^{26,27}$.

Erlotinib was licensed in December 2004 for the treatment of patients with advanced NSCLC who failed first- or second-line chemotherapy (Phase III trial conducted by NCIC). This drug is a well-tolerated second-line alternative to chemotherapy and even has possibilities as a third-line treatment where there was no previous benefit from chemotherapy ${ }^{27}$. 
Approval has been granted by the Food and Drug Administration for the treatment of patients with advanced non-small-cell lung cancer which has previously been treated with standard chemotherapy.

As targeted therapy, it is impossible to treat all patients in the same way, and it is necessary to identify clinical or biological factors that potentially predict responses in order to select those patients who could best benefit from anti-EGFR target therapy.

In our study, a response rate of $23 \%$ was obtained with a median progression free survival of 16 weeks from the end of second-line treatment, and a median overall survival of 79 weeks. Our results are similar to those obtained in the studies described above.

The comparative study between patients who received first-line chemotherapy with and without cisplatin revealed a response rate and median survival without significant difference.

Our study suggests that this two-drug combination could be a good alternative as second-line treatment, both in patients previously treated with cisplatin, and in those who were not. Data from other series also show that response rates and survival in second-line treatment are not dependent on the first-line chemotherapy with or without cisplatin. Only a small number of patients were included in our series and further studies will be necessary, but the excellent tolerability (mild-moderate levels of toxicity, without grade 4 toxicity) plus the efficacy, which is comparable to other schemes, make this combination a good choice, especially for elderly or weak patients.

We have reviewed the most important studies published on second-line chemotherapy of advanced non-small-cell lung cancer. These studies demonstrate clear benefits in survival and alleviation of symptoms, but with modest results, therefore further research is required. To define the appropriate management of both older and low PS patients, patient subsets who may benefit from more aggressive two-drug combination, as well as the integration of new target therapies either alone or in combination with cytotoxic treatment, is an area of active investigation that needs to be answered in ongoing clinical trials.

\section{Acknowledgments}

The authors wish to thank Martin Hadley-Adams for translating the manuscript and editorial assistance.

\section{Bibliography}

1. Kosmidis P, Mylonakis N, Nicolaides C, Kalophonos C, Samantas E, Boukovinas J, et al. Paclitaxel plus carboplatin versus gemcitabine plus paclitaxel in advanced nonsmall cell lung cancer: a phase III randomised trial. J Clin Oncol 2002; 20: 3578-85.

2. Belani CP, Barstis J, Perry MC, La Rocca RV, Nattam SR, Rinaldi D, et al. Multicenter, randomized trial for stage IIIB or IV non-small-cell lung cancer using weekly paclitaxel and carboplatin followed by maintenance weekly paclitaxel or observation. J Clin Oncol 2003; 21: 2933-9.

3. Kelly K, Crowley J, Bunn PA Jr, Presant CA, Grevstad PK, Moinpour CM, et al. Randomized phase III trial of paclitaxel plus carboplatin versus vinorelbine plus cisplatin in the treatment of patients with advanced non-small-cell lung cancer: a Southwest Oncology Group trial. J Clin Oncol 2001; 19: 3210-8.

4. Fosella F, Pereira JR, Von Pawel J et al. Randomized, multinational, Phase III Study of Docetaxel plus Platinum combinations versus Vinorelbine plus Cisplatin for advanced non small cell lung cancer: The TAX 326 Study Group. J Clin Oncol 2003;16: 3016-3024.

5. Belani CP, Lee JS, Socinski MA, et al. Randomized phase III trial comparing cisplatin-etoposide to carboplatin-paclitaxel in advanced or metastatic non-small-cell lung cancer. Ann Oncol 2005 Jul; 16(7): 997-8.

6. Ranson M, Davidson N, Nicolson M, Falk S, Carmichael J, López P, et al. Randomized trial of paclitaxel plus supportive care versus supportive care for patients with advanced non-small cell lung cancer. J Natl Cancer Inst 2000; 92: 1074-80.

7. Sculier JP, Berghmans T, Lafitte JJ, et al. A phase II study testing paclitaxel as second-line single agent treatment for patients with advanced non-small cell lung cancer failing after a first-line chemotherapy. Lung Cancer 2002; 37:7377.

8. Socinski MA, Schell MJ, Bakri K, et al: Second-line, lowdose, weekly paclitaxel in patients with stage IIIB/IV nonsmall cell lung carcinoma who fail first-line chemotherapy with carboplatin plus paclitaxel. Cancer 2002; 95:1265-1273

9. Koumakis G, Demiri M, Barbounis V, et al. Is weekly paclitaxel superior to paclitaxel given every 3 weeks? Results of a phase II trial. Lung Cancer 2002; 35:315-317

10. Juan O, Albert A, Ordono F, et al. Low dose weekly paclitaxel as second-line treatment for advanced non-small cell lung cancer. A phase II study. Jpn J Clin Oncol 2002; 32:449-454

11. Kakolyris S, Georgoulias V. The role of gemcitabine and paclitaxel as second-line chemotherapy for the treatment of advanced non small-cell lung cancer.Clin Lung Cancer 2000; 2(1):43-7.

12. Esteban E, González de Sande L, Fernández Y et al. Prospective randomised phase II study of docetaxel versus paclitaxel administered weekly in patients with non-small 
cell lung cancer treated with platinum-based chemotherapy. Ann Oncol 2003;14:1640-7.

13. Gridelli C, Perrone F, Gallo C, et al. Single-agent gemcitabine as second-line treatment in patients with advanced non small cell lung cancer:a phase II trial. Anticancer Res 1999; 19(5C):4535-8.

14. Sculier JP, Lafitte JJ, Berghmans T, et al. A phase II trial testing gemcitabine as second-line chemotherapy in non small cell lung cancer. Kakolyris S, Georgoulias V. The European Lung Cancer Working Party Lung Cancer 2000; 29(1):67-73.

15. Pectasides D, Kalofonos HP, Samantas E, et al. An out-patient second-line chemotherapy with gemcitabine and vinorelbine in patients with non small cell lung cancer previously treated with cisplatin-based chemotherapy. A phase II study of Hellenic co-operative Oncology Group. Anticancer Res 2001 Jul-Aug; 21(4B): 3005-10.

16. Shepherd FA, Dancey J, Ramlau R, et al. Prospective randomized trial of docetaxel versus best supportive care in patients with non small cell lung cancer previously treated with platinum based chemotherapy. J Clin Oncol 2000; 18:2095-2103.

17. Fosella FV, DeVore R, Kerr RN, et al. Randomized phase III trial of docetaxel versus vinorelbine or ifosfamide in patients with advanced non small cell lung cancer previously treated with platinum-containing chemotherapy regimens. J Clin Oncol 2000; 18:2354-2362.

18. Thongprasert S, Cheewakriangkrai R, Napapan S. Docetaxel as second-line chemotherapy for advanced non small cell lung cancer. J Med Assoc Thai 2002; 85(12):1296-300.

19. Hann N, Shepherd FA, Fosella FV, et al. Randomized phase III trial of pemetrexed versus docetaxel in patients with non-small cell lung cancer previously treated chemotherapy. J Clin Oncol 2004;22:1589-1597.

20. Lilenbaum R, Langenberg P, Dickersin K. Single agent versus combination chemotherapy in patients with advanced non-small cell lung carcinoma: A meta-analysis of response, toxicity, and survival. Cancer 1998; 82:116-126.

21. Oka M, Fukuda M, Nagashima S, et al. Phase I study of second-line chemotherapy with Docetaxel and Carboplatin in advanced non small cell lung cancer. Cancer Chemother Pharmacol 2001 Dec; 48(6): 446-50.

22. Laak E, Dierlamm T, Knuffmann C, et al. Docetaxel and Carboplatin as second-line chemotherapy for metastatic non-small-cell lung cancer. Lung Cancer 2002 Jun; 36(3): 303-7.

23. Numico G, Colantonio I, Gasco M et al. Carboplatin and weekly paclitaxel in non small cell lung cancer patients unfit or pretreated with chemotherapy. Anticancer Res 2005 May-Jun; 25(3c): 2555-9.

24. Hensing TA, Peterman AH, Schell MJ, et al. The impact of age on toxicity, response rate, quality of life and survival in patients with advanced, stage IIIB or IV non small cell lung carcinoma treated with carboplatin and paclitaxel. Cancer 2003 Aug 15; 98(4): 779-88.

25. Janmaat ML, Giaccone G. The epidermal grow factor receptor pathway and its inhibition as anticancer theraphy. Drugs today (Barc) 2003; 39 Suppl C: 61-80.

26. Hammond LA. Pharmacokinetic evaluation of gefinitib when administered with chemotherapy. Clin Lung Cancer 2003 Sep; 5 Suppl 1: S 18-21.

27. FH Blackhall, S Rehman and N Thatcher. Erlotinib in nonsmall cell lung cancer: a review. Expert Opin Pharmacother 2005; 6(6): 995-1002.

\author{
Correspondence: \\ Dr. R. Espinosa \\ Medical Oncology Service \\ Hospital Universitario Puerta de Hierro \\ C/ San Martín de Porres, 4 \\ E-28035 Madrid (Spain) \\ ruespi_1@hotmail.com
}

